\title{
Discursive Deficits: A Feminist Perspective on the Power of Technical Knowledge in Fiscal Law and Policy
}

Lisa Philipps

Osgoode Hall Law School of York University, Iphilipps@osgoode.yorku.ca

\section{Source Publication:}

Canadian Journal of Law and Society/Revue Canadienne Droit et Société. Volume 11, Issue 1 (1996), p. 141-176.

Follow this and additional works at: https://digitalcommons.osgoode.yorku.ca/scholarly_works (c) (i) $(9)$

This work is licensed under a Creative Commons Attribution-Noncommercial-No Derivative Works 4.0 License.

\section{Recommended Citation}

Philipps, Lisa. "Discursive Deficits: A Feminist Perspective on the Power of Technical Knowledge in Fiscal Law and Policy." Canadian Journal of Law and Society 11.1 (1996): 141-176.

This Article is brought to you for free and open access by the Faculty Scholarship at Osgoode Digital Commons. It has been accepted for inclusion in Articles \& Book Chapters by an authorized administrator of Osgoode Digital Commons. 


\title{
Discursive Deficits: A Feminist Perspective on the Power of Technical Knowledge in Fiscal Law and Policy*
}

\author{
Lisa Philipps \\ Osgoode Hall Law School \\ York University
}

\begin{abstract}
Decisions about taxation and government spending have great political significance: they affect the distribution of income and wealth and the nature and degree of class, gender and other social inequalities. However, tax and budgetary issues are frequently constructed as technical matters that can be resolved rationally according to economic, mathematical or other ostensibly neutral principles. The author examines the debate around budget deficits and recent sex equality challenges to the income tax system, and argues that both illustrate how technical discourses tend to deny the normative content of fiscal law and policy and to disqualify political opposition to the prevailing fiscal order as irrational, ideological and inexpert. The paper concludes by examining the discursive strategies of feminists and others interested in fiscal change. The author considers how feminists might respond to, and even harness, the power of technical knowledges in struggling for tax and expenditure reforms while also challenging the oppressive features and depoliticizing tendencies of such discourses.
\end{abstract}

Résumé - Les mesures fiscales et les décisions relatives aux dépenses publiques revêtent une grande importance : elles touchent la distribution du revenu et des richesses ainsi que la nature et l'étendue des inégalités d'ordre social. Toutefois, les questions d'ordres fiscal et budgétaire sont le plus souvent traitées comme des questions techniques qui commandent des solutions rationnelles reposant sur des principes économiques, mathématiques ou, du moins, en apparence neutres. Dans le présent article, l'auteure fait état du débat sur la question du déficit budgétaire et des récentes tentatives visant à dénoncer les inégalités de sexe existant dans le système fiscal; selon elle, cette polémique illustre la façon dont le jargon technique tend à masquer le contenu normatif de la politique et de la loi fiscales et à contrer toute forme d'opposition à l'ordre

I wish to acknowledge the helpful feedback I received on earlier versions of this paper from Neil Brooks, Judith Grbich, Marlee Kline, Greg Levine, Martha Minow, Nancy Staudt, Kathy Teghtsoonian, Mark de Weerdt, Margot Young, participants in the Critical Tax Theory Workshop held at SUNY-Buffalo School of Law in September 1995, and journal referees. 
fiscal établi en la taxant d'irrationnelle, idéologique et simpliste. L'auteure conclut en faisant l'étude des stratégies discursives des groupes féministes et d'autres groupes visant le changement de la politique fiscale. Elle y suggère des méthodes permettant aux féministes de contrer à leur tour, sinon de neutraliser, le pouvoir du savoir technique afin d'obtenir les réformes fiscales et budgétaires voulues et remettre en question l'arbitraire et la tendance à la dépolitisation d'un tel jargon.

This paper draws connections between two issues that initially may seem rather far apart. The first is the country's political preoccupation with reducing government deficits and debt. ${ }^{1}$ The second is the Supreme Court of Canada's rejection of two feminist challenges to the Income Tax Act, ${ }^{2}$ in the cases of Symes v. Canada ${ }^{3}$ (regarding the deductibility of child care expenses from business income) and Thibaudeau v. Canada ${ }^{4}$ (on the taxation of child support payments). What does this recent jurisprudence have in common with the debate over budgetary deficits? Both are certainly within the realm of fiscal policy, having to do with taxes and government expenditures. ${ }^{5}$ But more importantly, I argue, both demonstrate the power of technical discourses in shaping the fiscal order and in reproducing social and economic inequalities.

No great powers of observation are needed to notice that both tax law and fiscal policy formation are dominated by a relatively small and elite group of experts. Nor would many dispute the inaccessibility of the technical language in which these issues are often discussed. In this paper, I focus on the way these technical discourses tend to deny the normative content of tax law and policy, and thus to deflect political challenges to the prevailing fiscal order. In this manner, technical discourses work to protect the interests of the relatively wealthy and powerful, and to sustain and legitimate the economic marginalization of women and other subordinated groups.

In the sections which follow, I develop this argument in three stages. The first looks at some historical and cultural reasons that help explain why technical knowledge has so much clout in the fiscal area, and sets out a framework for

1. In this paper, $\mathrm{I}$ use the terms "deficit" and "debt" interchangeably. For clarity, however, it should be noted that a deficit is a shortfall of government revenues in relation to expenditures for any given year. Debt refers to the accumulated stock of outstanding debts owed by a government as a result of financing previous years' budget deficits.

2. R.S.C. 1985, (5th Suppl.), c.1, as am. [hereinafter ITA].

3. [1993] 4 S.C.R. 695 [hereinafter Symes].

4. [1995] 2 S.C.R. 627 [hereinafter Thibaudeau].

5. The term "fiscal policy" refers to the "[e]xpenditure and taxation policies that underlie a government's budget." See J. McMenemy, The Language of Canadian Politics, rev. ed. (Waterloo: Wilfred Laurier University Press, 1995). 
analyzing the gendered politics of this phenomenon. In the second part, I look at the debate around budget deficits and how technical discourses advance certain political values in this debate while simultaneously asserting their own neutrality and objectivity and disqualifying oppositional discourses as sentimental and irrational. The third part considers how feminists and others committed to political change might engage with the technical in challenging the tax system and the larger fiscal order. The Supreme Court of Canada's rulings in Symes and Thibaudeau serve to highlight the ideological power of the tax system's claim to neutrality and the difficulty feminists face in trying either to deconstruct or to transform the technical discourses that support this claim. In Thibaudeau particularly, the Court privileges the language and concepts of fiscal policy so as to place them virtually beyond the reach of equality rights discourse. In this final part, I consider what discursive strategies might help to advance feminist political aims in the fiscal area, and the possibilities and dangers that lie in appropriating technical discourses to our own uses.

\section{The Politics of Technical Talk: Normalizing Inequality}

There are many ways in which the current fiscal regime contributes to social inequality. The very existence of something called "state fiscal policy" says a great deal about the sanctity of private property in our society. It presupposes a separation of public and private realms in which the tax system limits how far the state, in pursuit of collective goals, can legitimately encroach upon the property rights of individuals. ${ }^{6}$ Inequalities associated with the market are implicitly conceived as natural, and susceptible only to limited correction by governments. Moreover, the tax system is often assumed to be more redistributive than it actually is. ${ }^{7}$

The personal income tax is in principle based on ability to pay, reflected in the nominally progressive marginal rate schedule, ${ }^{8}$ but its actual progressivity is diminished by several factors. First among these is the wide variety of special concessions in the form of deductions, credits, deferrals and exclusions from

6. See J. Schumpeter, "The Crisis of the Tax State", trans. W. F. Stolper \& R. A. Musgrave, in A. T. Peacock, W. F. Stolpar, R. Turvey \& E. Henderson, eds., International Economic Papers, no.4 (London \& New York: Macmillan,1954) 5.

7. For a thorough and engaging analysis of the regressive elements of the tax system and how they have been exacerbated by tax policy changes since 1988 , see N. Brooks, "The Changing Structure of the Canadian Tax System: Accomodating the Rich" [1993] 31 Osgoode Hall L.J. 137. See also L. Panitch, "Beyond the Crisis of the Tax State? From Fair Taxation to Structural Reform" in A. M. Maslove, ed., Fairness in Taxation: Exploring the Principles (Toronto: University of Toronto Press, 1993) 135.

8. ITA, s.117(2). 
income, that disproportionately benefit those with higher incomes. ${ }^{9}$ These socalled tax expenditures reduce the effective rates applicable to some taxpayers, providing them with a financial subsidy just as though they had received a direct payment from the government. ${ }^{10}$ Second, the personal income tax is only one component of the total tax mix. A large share of government revenue is obtained through other taxes, many of which have a regressive incidence, such as sales taxes imposed at flat rates regardless of income level. ${ }^{11}$ The fact that Canada does not impose personal wealth taxes, which generally are strongly progressive, is also significant in this regard. ${ }^{12}$ Finally, courts have tended to favour interpretations of tax law which place a high value on the individual or corporate person's liberty to avoid taxes. ${ }^{13}$ In practice, sophisticated avoidance planning is

9. For a study of the incidence of personal tax expenditures by income bracket, see F. St. Hilaire, For Whom the Tax Breaks, vol. 2, no 2 (Institute for Research on Public Policy, 1996). A list of tax expenditures and their cost in foregone revenue is available in Government of Canada, Personal and Corporate Income Tax Expenditures (Ottawa: Department of Finance, 1993). See also N. Brooks, Paying for Civilized Society: The Need for Fair and Responsible Tax Reform (Ottawa: Centre for Policy Alternatives, 1990); J. B. Davies, "Distributional Effects of the Lifetime Capital Gains Exemption: Single vs. Multi-Year Analysis" (1995) Canadian Public Policy (XXI Supplement) S159; K. Lahey, "The Small Business Credit: A Tax Expenditure Analysis" (1979) 1 Canadian Taxation 29.

10. See E. A. Lindquist, "Improving the Scrutiny of Tax Expenditures in Ontario: Comparative Perspectives and Recommendations" in A. M. Maslove, ed., Taxing and Spending: Issues of Process (Toronto: University of Toronto Press, 1994) 32; N. Bruce, ed., Tax Expenditures and Government Policy (Kingston, Ont.: John Deutch Institute for the Study of Economic Policy, 1988).

11. See N. Brooks, supra note 7; Royal Commission on Taxation, The Incidence of Taxes and Public Expenditures in the Canadian Economy, Study No. 2 by W. I. Gillespie, (Ottawa: Queen's Printer, 1966); W. I. Gillespie, The Redistribution of Income in Canada (Ottawa: Institute of Canadian Studies, Carleton University, 1980).

12. See M. Maloney, "Distributive Justice: That is the Wealth Tax Issue" (1988) Ottawa Law Review 601; L. Philipps, Taxing Inherited Wealth: Ideologies About Property and the Family in Canada (LL.M. Thesis, York University, 1992) at 3870; Wealth Tax Working Group Report (Ontario Fair Tax Commission, 1993).

13. Tax statutes traditionally were subject to a strict construction rule in Canada. In recent years, the courts have ostensibly modified this rule to take into account the object and spirit of the legislation: see Stubart Investments Ltd. v. The Queen, [1984] 1 S.C.R. 536. However, in practice, the courts have continued to prefer interpretations that leave ample leeway for tax avoidance: see, for example, JohnsManville Canada Inc. v. The Queen, [1985] 2 S.C.R. 46; McClurg v. The Queen, [1990] 3 S.C.R. 1020; The Queen v. Irving Oil Limited (1991), 126 N.R. 47 (F.C.A.) [leave to appeal to S.C.C. denied]; Antosko v. The Queen, [1994] 2 S.C.R. 312; Corporation Notre-Dame de Bon-Secours v. Communauté urbaine de Québec and City of Québec, [1994] 3 S.C.R. 3, at 19, where the Court quoted approvingly 
available almost exclusively to those who own substantial amounts of business or investment property.

I do not wish to suggest that the fiscal system is monolithically oppressive, or to deny that political struggle has resulted in some meaningful redistributive reforms. ${ }^{14}$ The point is there are also many ways in which tax law sustains and deepens patterns of social inequality. It should also be noted that the benefits and burdens of taxation are distributed unequally not only in terms of class, but along lines of gender, sexual orientation, and other markers of social difference..$^{15}$

In this paper, I want to approach the relationship between budgetary policy and inequality from a somewhat different angle. I argue that the political dynamics just noted are complemented by the technical discourses of fiscal law and policy. Such discourses tend to reinforce the patterns of inequality mentioned above, while simultaneously serving the equally important function of legitimating and normalizing them. They achieve this by framing what are essentially political issues as purely technical questions susceptible of neutral solutions. To borrow Carol Smart's words, they give the discourse a claim to "scientificity," conferring upon it a privileged status as objective, apolitical truth, and disqualifying other knowledges which might challenge the fiscal order. ${ }^{16}$ The next section focuses on tax law to illustrate this discursive effect.

from its judgment in Johns-Manville Canada (ibid.), as follows: "reasonable uncertainty or factual ambiguity resulting from lack of explicitness in the statute should be resolved in favour of the taxpayer." On the ability of advantaged groups to influence the bureaucratic administration of the tax system, see L. Sossin, "Redistributing Democracy: An Inquiry into Authority, Discretion and the Possibility of Engagement in the Welfare State" (1994) 26 Ottawa Law Review 1.

14. See, for example, R. Krever, "The Origin of Federal Income Taxation in Canada" (1981) 3 Canadian Taxation 170, on the struggle to introduce progressive income taxation in the early part of this century.

15. See, for example, A. Macklin, "Symes v. MNR: Where Sex Meets Class" (1992) C.J.W.L. 498; M. Maloney, "Women and the Income Tax Act: Marriage, Motherhood and Divorce" (1989) C.J.W.L. 182; L. Philipps, "Tax Policy and The Gendered Distribution of Wealth" in I. Bakker, ed., Rethinking Restructuring: Gender and Change in Canada (Toronto, Buffalo, London: University of Toronto Press, 1996) 141 [hereinafter "Tax Policy"]; L. Philipps \& M. Young, "Sex, Tax and the Charter: A Review of Thibaudeau v. The Queen" (1995) 2 Review of Constitutional Studies 221; C. Young, "(In)visible Inequalities: Women, Tax and Poverty" (1995) 27 Ottawa Law Review 99; C. Young, "Taxing Times for Lesbians and Gay Men: Equality at What Cost?" (1994) 17 Dalhousie L.J. 534. See also Women and Taxation Working Group Report (Ontario Fair Tax Commission, 1993).

16. C. Smart, Feminism and the Power of Law (London: Routledge, 1989) at 9 [drawing on Foucault]. 


\section{The Technical in Tax Law}

What is a technical discourse? The term has several layers of meaning, as it is used in this paper. Tax law is technical in the dictionary sense that it is a specialized field of knowledge, with its own language, involving a terminology and grammatical style that is not readily accessible to persons without specialized training. This inaccessibility is not merely a function of complexity or excessive detail. Indeed, bits of jargon and special terms can be used to bestow authority on even the most superficial or oversimplified analyses. ${ }^{17}$

In addition, tax law is affiliated with certain other discourses that are technical in the same sense of being specialized fields of knowledge: economics, accounting, public finance theory, traditional tax policy analysis. Aspects of these discourses have been imported into, and internalized within tax law, though judges in tax cases are quick to assert that such external knowledges always remain subject to any overriding legal principles. ${ }^{18} \mathrm{I}$ think this is an example of the phenomenon observed by Smart, in which law "sets itself above" 19 other, non legal discourses, while simultaneously incorporating selected aspects of those discourses for its own purposes. ${ }^{20}$ Smart argues that this allows law to extend its reach and maintain its power in modern society by allying itself with those knowledges that are important to what Foucault has termed the "disciplining of the social body." 21

There is a further dimension to the term "technical," one which goes beyond mere specialized knowledge. It also implies a form of knowledge which is scientific in nature, and this claim to scientificity is central to the power of technical discourses. The relationship between the technical and the scientific is not as straightforward as it first appears. Certainly, both are concerned with method and systematicity. But the strong association of these terms is primarily due to the fact that both refer in somewhat different ways to superior forms of knowledge; the former quite explicitly in terms of expertise, the latter more

17. Thanks to Neil Brooks for this point.

18. See B. Arnold, Timing and the Taxation of Income: The Principles of Income Measurement for Tax Purposes, Canadian Tax Paper No. 71 (Toronto: Canadian Tax Foundation, 1983) c. 1, on the relationship between accounting and legal principles in the determination of profit for tax purposes. See also Friesen v. Canada, [1995] 3 S.C.R. 103, where the Court referred to accounting principles to assist in determining whether the taxpayer's land qualified as "inventory" for the purposes of s. 10(1) of the ITA. Both the majority and dissenting judges accepted that express language in the ITA overrides accounting principles where the two are in conflict. However, they disagreed on whether there was such an inconsistency in the case at bar (per Major J. at 123, 124; and Iacobucci J. at 170, 171).

19. Supra note 16 at 10.

20. Ibid. at $14-20$.

21. Ibid. at 17. 
obliquely through the claim to objectivity and pure truth. The construction of the technical discourses in and around tax law as scientific feeds into a powerful ideology in our culture about the nature of truth and knowledge.

\section{Science and Truth}

The glorification of empirical and scientific knowledge in Western cultures can be traced back to the Enlightenment period of the 16th and 17th centuries, and what Susan Bordo has so aptly termed "the flight to objectivity." 22 Bordo describes the reconstruction of philosophical and epistemological paradigms that occurred during this period as involving a radical separation of human intellect from the body and physical nature. The organic universe of the Middle Ages was thus shattered, and nature revisioned as a mechanistic force to be brought under control by a superior human intelligence and will. The human body, its senses and appetites, were constructed in total opposition to reason, and as the chief impediment to knowledge and truth. The purest, most reliable knowledge became that which was free of any perspective derived from bodily location in time and space. The legacy of this reconstruction has been a model of scientific inquiry in which the subject and object, the knower and the known are required and assumed to be radically separate.

Bordo and others have illuminated the deeply gendered nature of this paradigm of knowing and being. The physical universe abandoned as inferior in the 17 th century was distinctly female. In the cultural ideology that grew out of the Enlightenment, the association of women with the physical, bodily dimensions of life served to facilitate and normalize their social and political subordination. ${ }^{23}$ As Lorraine Code has put it:

[T] he ideals of rationality and objectivity that have guided and inspired theorists of knowledge throughout the history of western philosophy have been constructed through processes of excluding the attributes and experiences commonly associated with femaleness and underclass social status: emotion, connection, practicality, sensitivity, and idiosyncrasy. ${ }^{24}$

22. See S. Bordo, The Flight to Objectivity: Essays on Cartesianism and Culture (Albany: State University of New York Press, 1987).

23. Ibid. at c. 6; see also S. Bordo, Unbearable Weight: Feminism, Western Culture, and the Body (Berkeley: University of California Press, 1993).

24. L. Code, "Taking Subjectivity into Account" in L. Alcoff \& E. Potter, eds., Feminist Epistemologies (New York: Routledge, 1993) 15 at 21. Like Code, Bordo recognizes that the association of gender with different ways of knowing preceded the Enlightenment and has much earlier roots. However, Bordo argues that the work of Descartes represented a quantum shift towards the total opposition of mind and body, and a more thorough subordination of the female. 
Bordo identifies several layers to this masculinization of science and rationality. ${ }^{25}$ She discusses the history of discrimination by a scientific establishment that has doubted whether women practitioners can measure up to the rigour or clarity science demands. In addition, scientific doctrine itself can be biased by assumptions or inferences that are sexist, homophobic, racist, etc. And finally, scientific method is dominated by a particular cognitive style or epistemological stance, necessary for research to be accepted as authoritative.

The post-Enlightenment faith in rationality as the means to truth extends far beyond scientific practice per se. It pervades the organisation of social relations at many levels. Theorists of many disciplinary and political stripes have seen this as a key feature of the way power is exercised in modern western cultures. Writings about the rise of "technocracy," "technopoly," the "technocorporate state," the "technological society," and Foucault's "disciplinary society'," while they encompass a wide range of perspectives, also share some common themes in their description of modern social arrangements. ${ }^{26}$ These include:

(i) the polarization of the work process and society into expert and nonexpert sectors, along lines of class, race and sex;

ii) the increasing power of scientific knowledge and technical expertise as the only, or the most legitimate bases of authority;

iii) the subordination/disqualification of other knowledges or languages; and

iv) the belief that technical knowledge holds the answer to all social problems, and displaces traditional interest-group politics and moral judgment.

Within this cultural context, quantification has become a central means of understanding and describing the world. Ellul is critical of the scientific attitude for paying heed only to that which can be expressed numerically. He comments ironically that, "[t]o get away from the so-called 'arbitrary and subjective,' to escape ethical or literary judgments (which, as everyone knows, are trivial and unfounded), the scientist must get back to numbers. What, after all, can one hope

\section{Supra note 22 at 104 .}

26. See B. H. Burris, "Technocratic Organization and Gender" (1989) Women's Studies International Forum 447; B. H. Burris, Technocracy at Work (Albany: State University of New York, 1993) [hereinafter Technocracy at Work ]; J. Ellul, The Technological Society (New York: Alfred A. Knopf, 1965); K. Ferguson, The Feminist Case Against Bureaucrasy (Philadelphia: Temple University Press, 1984); F. Fischer, Technocracy and the Politics of Expertise (Newbury Park, CA: Sage Publications, 1990); M. Foucault, "Power/Knowledge" in Colin Gordon, ed., Power/Knowledg: Selected Interviews and Other Writings, 1972-1977/Michel Foucault (New York: Pantheon Books, 1980) esp. at 131; U. Franklin, The Real World of Technology (Concord, Ont.: Anansi, 1990); N. Postman, Technopoly: The Surrender of Culture to Technology (New York: Alfred A. Knopf, 1992). 
to deduce from the purely qualitative statement that the the worker is fatigued?" 27

Likewise, Postman decries our "mathematical concept of reality," in which only quantitative measures are seen as authentic expressions of knowledge. ${ }^{28}$ This poses a political problem for those who wish to challenge oppression and its harmful effects on human beings. When juxtaposed with scientific understandings of society, narratives about the quality of human experience may be discounted as belonging to another mentality, one that is primitive, irrational, custom-based, mythical, ideological, and biased. ${ }^{29}$

Postman stresses the importance of what he calls technical machinery in advancing the quantitative version of reality. Standard forms, taxonomies, public opinion polls, and other tools operate by translating multifaceted, complex realities into technical, precise and unidimensional terms which then become the truth for us. He ascribes a similar function to statistics in their reduction of human qualities to quantities. Our enchantment with the apparent objectivity of these numbers tends to obscure the subjectivity of choices about what should be the subject of measurement, and what goals technical means should strive towards. ${ }^{30}$

I do not wish to suggest that these technocratic tendencies are unrelievedly negative. Many social theorists have emphasized the power of objective, scientific knowledge to challenge established structures of authority and belief, arguing that the rise of technical discourse signals a movement towards a more democratic order based on reason and merit. ${ }^{31}$ Whether or not one is prepared to concede the existence of any objective truth that can be revealed through science, the discursive power of scientific argument can be of great value to feminists and others who seek to delegitimate those conventional wisdoms that contribute to oppression. As I discuss in the next section, however, technical discourses can also have profoundly undemocratic and socially regressive effects. This tension between the democratic and hegemonic capacities of technical knowledge raises difficult political and strategic questions for advocates of social change. It is ironic, however, that both the democratic and hegemonic perspectives recognize an important element of duplicity in technical discourse, that is its ability to advance a particular politics in part by denying that it is doing so. Scientific and technocratic discourses rest upon an ideology of value-neutrality or an ideology of non-ideology.

\section{Ellul, ibid. at 18.}

28. Ibid., c. 1.

29. J. F. Lyotard, The Postmodern Condition (Minneapolis: University of Minnesota Press, 1984), quoted in Burris, Technocracy at Work, supra note 26 at 48.

30. Postman, supra note 26 at $89-91$.

31. For an account of the history and ideologies of technocratic thought, see Burris (1993), supra note 26 at c. 2. 


\section{Technical Discourse and Ideology}

The relationship between discourse and ideology has been fraught with controversy. While a thorough exposition of the issues is beyond the scope of this paper, I take the view that both concepts offer something useful in terms of explaining the relationship between power and knowledge, that each is rather limited without the other, and that they provide complementary rather than opposing or mutually exclusive analyses of social life. ${ }^{32}$

The concept of discourse emphasizes the role of language in constructing the truth and knowledge of a society, and sees language as a site of struggle and a medium for the exercise of power. Thus truth consists not in some external reality, but in "the rules according to which the true and the false are separated and specific effects of power attached to the true." 33 Each society has its own regime or general politics of truth; "that is, the types of discourse which it accepts and makes function as true." ${ }^{34}$ In our era, truth is located in the form of scientific discourse, and the institutions which produce it. ${ }^{35}$ As Ursula Franklin has remarked (quoting Ruth Hubbard), scientists are the "socially sanctioned fact-makers" of our time. ${ }^{36}$ This is true not only of the natural or physical sciences, but of social science disciplines as well. Indeed, the claim to scientific rationality in any context can be seen as an exercise of power.

$I$ argue in the next part that the problem of budgetary deficits has been constructed through technical discourses that derive their power in part from their connection to the truth-telling regime of scientific rationality. I suggest that it is important to problematize these discourses by exposing the politics and partiality of technical and quantitative knowledge. I think there is currently a lack of epistemological space for other discourses to address the qualitative moral and political choices underlying deficit reduction policies, and the daily impact of those policies on less powerful citizens.

32. For a fuller discussion, see especially Philipps \& Young, supra note 15 at 247-50. See also S. Boyd, "Some Postmodernist Challenges to Feminist Analysis of Law, Family and State: Ideology and Discourse in Child Custody Law" (1991) 10 Canadian Journal of Family Law 79; B. Cossman, "Family Inside/Out" (1994) 44 University of Toronto Law Journal 1; T. Purvis \& A. Hunt, "Discourse, Ideology, Discourse, Ideology, Discourse, Ideology ..." (1993) 44 British Journal of Society 473; M. Kline, "The Colour of Law: Ideological Representations of First Nations in Legal Discourse" (1994) 3 Social \& Legal Studies 451; C. Weedon, Feminist Practice \& Poststructuralist Theory (Oxford: Basil Blackwell, 1987) at 27-32.

33. Foucault, supra note 26 at 132.

34. Ibid at 131.

35. Ibid.

36. U. Franklin, "From Knowledge to Power: Has Science Policy Swallowed Science?" (Lecture at the University of Victoria, 30 September 1994) [unpublished]. 
The concept of ideology is helpful in unpacking this relationship between fiscal discourse and larger patterns of social and economic inequality. It best captures the way that technical discourses elide their own politics, asserting their own neutrality while at the same time advancing particular norms about how society should be ordered. I use the term 'ideology' here to refer to clusters of beliefs, attitudes and images through which the power relations of a society are presented as natural and uncontestable. As Kline has written, the concept of ideology problematizes the common sense of a society, asserting that it "has developed historically, within particular relations of race, gender, class and sexual identity, and so on." ${ }^{37}$ Ideology and discourse are related in that discourse is the medium in which multiple ideologies conflict, intersect, and interact to produce knowledge. ${ }^{38}$

What is interesting about technical discourses is not just that they exercise power through their claim to scientificity and through their own normative frameworks but that they simultaneously deny they are doing so. They are able to juggle this contradiction through their close alliance with the rationalist ideology discussed earlier in this Part, that separates value from fact, subject from object, and normative from descriptive. Fischer describes this process as "the translation of basic normative questions into technical issues pertaining to instrumental means, [whereby] technical rationality and its 'value-neutral' methodologies disengage decisions from the social and political contexts that give them meaning." ${ }^{39}$ This disengaging effect poses a threat to democratic values.

The danger is that, by removing issues from the realm of political discourse into the language of science, technical discourses reduce the space for participation in decisions and reserve the discussion for those constructed as experts. ${ }^{40}$ Experts are indeed asked to solve all sorts of non technical problems, on which they may be uniquely unqualified to speak because of the narrowness of their knowledge and training. ${ }^{41}$ Moreover, the specialized language of experts makes their deliberations inaccessible to most people. Writing about economists, for example, Ellul describes their discipline as "The Secret Way," involving a vocabulary which is "incomprehensible to the outsider even when it is employed, as often happens, to enunciate the most obvious facts." ${ }^{12} \mathrm{He}$ goes so far as to assert that "[n]o democracy is possible in the face of a perfected

37. Kline, supra note 32 at 452 .

38. Ibid. at 453 . See also authors cited at note 32 .

39. Fischer, supra note 26 at 359.

40. Burris, Technocracy at Work, supra note 26 at 45 , drawing on M. Foucault, Discipline and Punish (New York: Vintage, 1977).

41. Postman, supra note 26 at $87 \mathrm{ff}$.

42. Ellul, supra note 26 at 162. 
economic technique." ${ }^{43}$ Similar kinds of fears are warranted in relation to fiscal discourse.

Taxation has profound political implications for all citizens because of its effect on the distribution of income and wealth among individuals and social classes. Tax policy development, however, has been captured to a large degree by specialists. In discussing budgetary processes, Doern describes the "tax policy community" as a group comprised primarily of "tax lawyers, accountants, and financial experts who represent corporate and other clients and actually understand and deal with the details of the tax system and of tax laws." 44 Douglas Hartle, former research director for the Royal Commission on Taxation during the 1960s (also known as the Carter Commission), has expressed concerns about the political impact of the "massive upgrading of the quantity and quality of expertise" 45 in the tax policy field. He worries that tax reform debates "will be dominated by highly technical discussions that will not be communicated to the general public and, even more important, some of the larger (and dare I say more important?) issues will not be addressed at all." 46 In fact, he suggests, it was the very lack of specialized training among the Commission's staff that led it to recommend quite radically progressive changes to the tax system which met with tremendous opposition from tax professionals and the business community, and ultimately from the government as well. ${ }^{47}$

It must also be remembered that the expert/non-expert distinction is a gendered one that has particularly excluded women from the realm of authoritative knowledge. While the objects that men make and manipulate tend to be coded as technical, the reproductive work that women most often do, and the objects they make and manipulate are constructed as nontechnical, natural, and humanistic. ${ }^{48}$ Further, Burris' work demonstrates that, at least in the United States, the expert/non-expert hierarchy in the paid labour force is structured not

\section{Ibid.}

44. G. B. Doern, "Fairness, Budget Secrecy, and Pre-Budget Consultations in Ontario, 1985-1992" in A. M. Maslove, ed.,Taxing and Spending: Issues of Process (Toronto: University of Toronto Press, 1994) 1 at 13.

45. D. Hartle, "Some Analytical, Political and Normative Lessons from Carter" in N. Brooks, ed., The Quest for Tax Reform (Toronto: Carswell, 1988) 401 at 403.

46. Ibid.

47. Ibid. On the political resistance to the Carter Commission Report and the role of tax professionals in this process, see L. T. MacDonald, Taxing Comprehensive Income: Power and Participation in Canadian Politics, 1962-1972 (Ph.D. dissertation, Carleton University, 1985) [hereinafter Taxing Comprehensive Income];L. T. MacDonald, "Why the Carter Commission Had To Be Stopped" in Brooks, ed., supra note 45 at 351 .

48. S. Curry Jansen, "Gender and the Information Society: A Socially Structured Silence" (1989) Communication 196. See also Franklin, supra note 26, at 16 , where she notes that "[ $w]$ hen certain technologies and tools are predominantly used by men, then maleness becomes part of the definition of those technologies." 
only by gender but by race and class. ${ }^{49}$ The tendency to disqualify women's knowledge as unobjective or irrational plays out in a variety of ways in the legal system, for example when the evidence of (frequently male) experts is relied upon to define and validate women's experiences of violence. ${ }^{50}$ Undoubtedly, the admission of expert evidence about "battered women's syndrome" or "rape trauma syndrome" can be beneficial in helping women secure greater legal protection from assault. What I wish to draw attention to here, however, is the fact that women's own accounts of this reality do not carry the same authority as those of a professionally or scientifically trained expert who inevitably reinterprets the women's experience through the lens of the expert discourse. This raises questions about how technical discourses may both advance and undermine feminist challenges to the legal system, questions which resurface in the final part of the paper.

What is the ideological content of technical discourses beyond their insistence that they have no ideology and represent a superior form of knowledge? One of the hallmarks of such discourses is that they avoid explicit discussion of any ends or goals whatsoever, focusing only on determining the best, most efficient means. As Lacey has put it, "all too often the actual specification of the relevant goals and values is avoided, being obscured within a discourse in which efficiency appears to become the end as well as the means." 51 This depoliticization is superficial only, however, in that the emphasis on control, stability, and efficiency amounts to an ideology of system preservation that places the larger question about what kind of system we want beyond the bounds of discussion. ${ }^{52}$ In this manner, technical discourses play an active part in normalizing and sustaining the social and economic inequalities produced by fiscal law and policy.

This is not to suggest that such discourses are merely willfully blind to inequality. Beyond a simple preference for the status quo, they may also actively promote certain ideologically specific forms of social ordering over others. Specific bits of technical discourse can be loaded with any number of cultural ideologies through the assumptions they make, the questions they ask, what evidence they find to be relevant, and what conclusions they draw from a body of evidence. For instance, statistics allow for the exercise of bureaucratic power "by determining classifications within which people must think of themselves

49. Burris, supra note 26.

50. See M. Shaffer, "R. v. Lavallee: A Review Essay" [1990] 22 Ottawa Law Review 607; and Smart, supra note 16 at 47.

51. N. Lacey, "Government as Manager, Citizen as Consumer: The Case of the Criminal Justice Act 1991" [1994] 57 Modern Law Review 534 at 534.

52. See Burris, Technocracy at Work, supra note 26 at c. 6. 
and of the actions that are open to them." 53 A classic example is the collection of census data using an ideologically specific definition of a family unit that does not recognize the existence of lesbian and gay couples, or the extended family networks which are more prevalent in First Nations communities, rendering the unique experiences of these groups invisible ${ }^{54}$ Likewise, feminist economists have shown how the liberal ideology that sees human beings as autonomous, self-interested actors has shaped mainstream economic doctrine, obscuring the degree to which production in the public market place is dependent upon the private reproductive labour of women. ${ }^{55}$ The point is that technical discourses can help to produce and normalize inequalities by inserting dominant ideologies into fiscal law and policy, presenting such ideologies as part of an objective truth.

Feminist philosophers of science have deconstructed the notion of pure objectivity, demonstrating the impossibility of insulating scientific inquiry from its context of social values, beliefs, ideologies, and politics. Moreover, these theorists have gone beyond the "woman question in science," to consider "'the science question in feminism": "Is it possible to use for liberatory ends sciences that are apparently so intimately involved in Western, bourgeois, and masculine projects?" 56 In pursuit of this goal, they have attempted in various ways to explode the dualistic epistemology of traditional science, and have appealed for a new model of knowledge which places the scientist within the field of observation, and recognizes the locatedness of all knowledge. Harding's standpoint epistemology, for example, seeks to enhance scientific objectivity by giving greater weight to the questions, experiences and observations of the marginalized. ${ }^{57}$ Longino's model of science as socially produced attempts to recognize the vulnerability of all science to political interests and values, while

53. I. Hacking, "How should we do the history of statistics?" in G. Burchell, C. Gordon \& P. Miller, eds., The Foucault Effect: Studies in Governmentality (Chicago: University of Chicago Press, 1991) 181 at 194.

54. See Philipps, "Tax Policy", supra note 15.

55. See, for example, P. England, "The Separative Self: Androcentric Bias in Neoclassical Assumptions" in M. A. Ferber \& J. A. Nelson, eds., Beyond Economic Man: Feminist Theory and Economics (Chicago: University of Chicago Press, 1993) 37; N. Folbre \& H. Hartmann, "The Rhetoric of Self-Interest: Ideology and Gender in Economic Theory" in A. Klamer, D. McCloskey \& R. Solow, eds., The Consequences of Economic Rhetoric (Cambridge: Cambridge University Press, 1988) 184.

56. S. Harding, Whose Science? Whose Knowledge? (Ithaca, NY: Cornell University Press, 1991) at vii.

57. Ibid. See also S. Harding, "Rethinking Standpoint Epistemology: What is 'Strong Objectivity'?" in L. Alcoff \& E. Potter, eds., Feminist Epistemology (New York: Routledge, 1993) 49. 
securing some guarantee of objectivity by exposing research to critical conversation within an inclusive scientific community. ${ }^{58}$

Such attempts to revise the dominant epistemology have generated lively debate, and disagreement still abounds as to the possibility of creating empirical or scientific knowledge which reflects and advances feminist political commitments. ${ }^{59}$ This debate bears directly on the question visited in the last part of this paper, which is whether and how feminists should deploy technical discourses in their struggles to change the fiscal system. Before pursuing this further, however, I want to apply some of the ideas developed so far to the problem of the deficit.

\section{Deconstructing the Deficit: Technical Discourses and Fiscal Policy}

In this part, I want to problematize what has become the dominant view in Canada, that governments must drastically reduce their social welfare spending, and that this is a matter of economic necessity rather than political choice. One of the reasons that deficit-fighting agendas have resisted political scrutiny so well, I argue, is that they have been framed discursively as belonging to the realms of economics, accounting, mathematics, statistics and other technical knowledges with a strong claim to scientificity.

Drawing on examples from government documents, think-tank publications, media reports and academic literature, I attempt to show how the deficit is constructed as a problem with one right answer, determinable through the apparently neutral tools of scientific analysis. Program cuts are thus presented as the only rational response to public debt, and other possible responses are disqualified as ideological, unobjective, unrealistic, uninformed, or sentimental. I argue that technical discourses have worked to depoliticize one of the most pressing social conflicts of our time, translating it into a matter of expert knowledge and shrinking the space for popular resistance to the harmful effects of such policies on many citizens. At the same time, they have helped to legitimate the way restraint policies exploit and deepen class, gender and other social inequalities by promoting an ideological vision of society in which market

58. H. Longino, Science as Social Knowledge: Values and Objectivity in Scientific Inquiry (Princeton: Princeton University Press, 1990).

59. For a sampling of different perspectives, see B. Bar On, "Marginality and Epistemic Privilege" in Alcoff \& Potter, eds., supra note 57 at 83; R. Campbell, "The Virtues of Feminist Empiricism" (1994) Hypatia 90; S. Crasnow, "Can Science Be Objective? Longino's Science as Social Knowledge" (1993) Hypatia 194; N. Tuana, "The Radical Future of Feminist Empiricism" (1992) Hypatia 100. 
power is minimally constrained, and individuals are held personally responsible for their own economic difficulties. ${ }^{60}$

\section{The Numbers Game}

One of the most striking features of mainstream accounts of the deficit issue are their heavy reliance on quantification and what Postman has called the mathematical version of reality. Dollar figures, percentages, and ratios are frequently presented as offering some self-evident information or conclusion, without explicit discussion of why or how a particular measurement is relevant, and without comparison to other relevant measures. This is nicely illustrated by a Pre-Budget Conference Workbook created by the Canada West Foundation at the request of the Department of Finance, to assist in public consultations prior to the 1994 federal budget. The Workbook begins with an "Economic Growth and Debt Quiz" for participants to test their knowledge. It consists of 12 multiple-choice questions, each one strongly numerical in focus. For example:

1. Canada's economy is the _largest in the world.

[(a) 5th; (b) 7th; (c) 12th; (d) 21 st] ...

7. By March of 1994, Canadians will owe __ in federal government debt.

[(a) $\$ 40$ billion, (b) 250 billion, (c) $\$ 510$ billion, (d) $\$ 700$ billion]

8. The single largest expenditure of the Government of Canada is, [(a) UI Payments, (b) Health, (c) Interest on Debt, (d) Social Assistance]

9. In the ten seconds it takes to read this question, the federal government will pay _ in interest on the debt:

[(a) $\$ 750$, (b) $\$ 1,520$, (c) $\$ 5,002$, (d) 12,530$] \ldots$

11. A Canadian family of four pays _ in taxes per month for interest on federal debt:

[(a) $\$ 57$, (b) $\$ 135$, (c) $\$ 204$, (d) $\$ 458]$

For participants who get fewer than seven of the answers correct, the Workbook says, "Uh oh-you really do need this workbook."61

This simple questionnaire reveals much about the way quantification can shape the production of knowledge, by making only certain kinds of facts relevant while excluding others from the discussion. First, the presentation of the issues in terms of figures only discourages any overt qualitative thinking about the moral and political implications of deficit reduction. The personal norms or experiences that might inform such judgments are marginalized by the suggestion that lack of knowledge about such figures will place one at a

60. See C. Denis, “'Government Can Do Whatever It Wants”: Moral Regulation in Ralph Klein's Alberta" (1995) 32 C.R.S.A. 365.

61. Incidentally, the answers are: $1(\mathrm{~b}), 7(\mathrm{c}), 8(\mathrm{c}), 9(\mathrm{~d}), 11(\mathrm{~d})$. 
disadvantage in the policy discussion to follow. The message is clear-this is the type of knowledge that counts.

This is a good example of what Postman described as technical machinery-technocratic tools that translate complex and multifaceted realities into unidimensional, quantitative facts with the aura of political neutrality. ${ }^{62}$ The same can be said of the graphs and charts that almost always accompany text on the deficit. Like the Globe and Mail's editorial page, these representations assert the point of view that "...pressure for reform [of social programs] in Canada arises much more from arithmetic than from ideology." 63 Federal Finance Minister Paul Martin has also declared that the debt and deficit are "facts of arithmetic" rather than "inventions of ideology." ${ }^{4}$ This assertion of rationality and exactitude is a way of claiming epistemic privilege for the dominant fiscal agenda, and disqualifying dissenting views. To echo Brodie, it "elevates economics over politics and suggests [fiscal restraint] ... is somehow inevitable, neutral, and beyond our control." 65

Beyond its overt emphasis on quantities, however, the quiz also presents a qualitative viewpoint on the deficit, in its choice of which numerical information is significant, and in the way it limits the range of possible answers to its own questions. Here we encounter the contradictory or duplicitous aspect of technical discourse in that it asserts particular normative positions while simultaneously denying that it is doing so. This contradiction is made possible by the ideology of scientific rationality discussed in Part I.

How does the quiz communicate a normative stance? First, question 8 associates debt with social spending, rather than other kinds of spending, or other possible causes of deficits. The current dominance of the idea that deficits are caused by government overspending is perhaps most powerfully illustrated by the rhetoric of the 1995 federal budget, which trumpeted the fact that new spending cuts would outstrip tax increases by a ratio of 7 to $1 .{ }^{66}$ The 1996

62. Postman, supra note 26.

63. “Abella's lament" The /Toronto] Globe and Mail (24 May 1995). In a similar vein, the same newspaper commented more recently that Mike Harris, the Conservative Premier of Ontario, "is not cutting out of spite. He is cutting because, unlike his predecessor [NDP Premier Bob Rae], he can count": "Is Mike Harris Really Heartless?" The [Torontol Globe and Mail (8 September 1995) A20.

64. Budget Speech (Ottawa: Department of Finance, Canada, 1995) at 2. More recently Martin showed that he understands the politics of speaking mathematically. In rejecting opposition calls for even more severe budgetary restraint he stated that "... draconian budgets are not difficult to write. The arithmetic is painless. But the human consequences are not." Budget Speech (Department of Finance, Canada, 1996) at 8.

65. J. Brodie, Politics on the Margins: Restructuring and the Canadian Women's Movement (Halifax: Fernwood Publishing, 1995) at 50.

66. Budget Speech (Ottawa: Department of Finance, Canada, 1995) at 4. 
federal budget continued with this theme by declaring that "governments created the deficit burden ... so governments must resolve it ... by getting spending down, not by putting taxes up." ${ }^{67}$ This account ignores the possibility that deficits could also be understood in terms of our failure to collect adequate tax revenues, particularly from wealthier groups, ${ }^{68}$ or our subsidization of private capital accumulation, and of services that predominantly benefit the already privileged in society. In light of the evidence which suggests that social spending has been a very small contributor to public debt, ${ }^{69}$ these programs have borne a disproportionate share of cutbacks in recent years. ${ }^{70}$ There is a substantial body of literature that points to other factors-tax expenditures, high interest rate policies, the cost of recessions and high unemployment-as bigger

67. Budget Speech (Ottawa: Department of Finance, Canada, 1996) at 7. The budget documents indicate that expenditure cuts account for $87 \%$ of the total combined fiscal actions in the Liberal government's three budgets: Budget Plan (Department of Finance, Canada, 1996) at 11. As a result of measures announced in these budgets, total program spending will fall by $\$ 14.5$ billion $(12.1 \%)$ over the fiveyear period from 1993-1994 to 1998-1999. By the final year, the government estimates that program spending will be at its lowest, relative to GDP, since 19491950 , and will be about $60 \%$ of what it was during the mid-1970s and mid-1980s (ibid. at 11-12).

68. See D. A. Wolfe, "The Politics of the Deficit" in G. B. Doern, The Politics of Economic Policy (studies for the Royal Commission on the Economic Union and Development Prospects for Canada, vol. 40) (Toronto: University of Toronto Press, 1985) 111. See also works cited, supra note 9.

69. See the controversial Statistics Canada study, "The Growth of the Federal Debt" (June 1991) 4:6 Canadian Economic Observer 3.1, which concluded that only a miniscule portion of the debt (less than $2 \%$ ) can be attributed to social welfare programs. Statistics Canada subsequentiy published a brief note which qualified certain aspects of this study, and expressed regret for having "added to controversy": "Note regarding the article "The Growth of the Federal Debt"" (1991) 3 Canadian Economic Observer.17. Linda McQuaig has asserted in her gripping journalistic account of the deficit issue that this note was published after Statistics Canada was subject to political pressure, particularly by the Department of Finance: L. McQuaig, Shooting the Hippo: Death by Deficit and Other Canadian Myths (Toronto: Viking, 1995) at 53-63.

70. Of the $\$ 25.6$ billion in expenditure cuts made by the 1994,1995 and 1996 federal budgets, reductions in cash transfers to the provinces for health care services, postsecondary education, social assistance and social services accounted for $\$ 7$ billion, or roughly 27\%; Budget Plan (Ottawa: Department of Finance, Canada, 1996) at 110. This figure does not include cuts to direct social spending by federal government departments. In Ontario, the Conservative government of Mike Harris reduced social assistance rates by over $21 \%$, to pay for approximately $20 \%$ of the government's total fiscal austerity program. See Masse v. Ontario (Ministry of Community and Social Services) Ontario Court of Justice (GD), 8 February 1996 $590 / 95$ at para. 367. 
culprits in the build-up of public debt. ${ }^{71}$ The preference for spending cuts also overlooks the danger of impairing our social stability, and our capacity for future economic productivity. ${ }^{72}$

Returning again to the quiz, questions 9 and 11 are obviously designed to appeal to economic fears. They make participants feel the deficit as an individual burden and as an imminent threat to their economic security. Nowhere does the quiz draw attention to the economic and social benefits derived from investments made with public borrowings, the amount of revenue collected in 10 seconds, the value of our accumulated national wealth, the fact that much interest on the debt is paid to Canadian investors and remains in our economy or, conversely, to the number of people added to food bank lines or the number of jobs lost due to welfare and other social program cuts. The sense of crisis around the deficit is highly functional for reducing resistance to severe belt-tightening measures. A United States government report on the politics of deficit reduction surveyed the experience of other countries, including Canada, and concluded with remarkable candor that "[l]eaders succeeded in using ... various appeals to promote a new sense of urgency about the deficit. Opposition parties and interest groups then had little choice but to frame their policies in a fiscal austerity context."73 As discussed in the next section, this air of crisis is often cultivated through metaphors of physical disaster.

Quiz question 11 obscures the unequal effects of fiscal policy on different groups by appealing to an image of a universal taxpaying family of four. This is a common theme of deficit literature, to construct all citizens as taxpayers

71. See G. B. Doern, A. M. Maslove \& M. J. Prince, Public Budgeting in Canada: Politics, Economics and Management (Ottawa: Carleton University Press, 1988) [reprinted 1991] at 20; P. Dungan \& T. Wilson, "Altering the Fiscal-Monetary Policy Mix: Credible Policies to Reduce the Federal Deficit" (1985) Canadian Tax Journal 309; P. Fortin, The Rising Federal Debt: Why, How Bad, What Should We Do? (Sainte-Foy: Université Laval, Groupe de Recherche en Politique Économique, May 1985); P. Fortin, "Let's Turn the Macroeconomic Policy Mix Upside Down" (1993) 14:6 Policy Options 15; C. Gonick, The Great Economic Debate (Toronto: James Lorimer, 1987) at 148-53; R. D. Kneebone, "Deficits and Debt in Canada: Some Lessons from Recent History" (1994) 22 Canadian Public Policy 152; McQuaig, supra note 69; G. Rosenbluth, "The Political Economy of Deficit-Phobia" in R. C. Allen \& G. Rosenbluth, eds., False Promises: The Failure of Conservative Economics (Vancouver: New Star, 1992) 61; Wolfe, supra note 68. See also Canadian Centre for Policy Alternatives and CHOICES, Alternative Federal Budget 1996 Framework Document (Ottawa: Canadian Centre for Policy Alternatives, 1996)

72. See L. Osberg, "Sustainable Social Development" in Allen \& Rosenbluth, eds., ibid. 227. See also "The Remaking of New Zealand" Ideas (transcript 12-19 October 1994, Canadian Broadcasting Corporation).

73. United States General Accounting Office, Deficit Reduction: Experiences of Other Nations (GAO/AIMD-95-30) (December 1994) at 54. 
positioned in essentially the same way in relation to the state. Lacey has noted a similar trend in Britain to construct citizens as fungible "consumers" of public services, and warns that such a concept of citizenship effectively sidelines those who lack the material or cultural resources to access public services equitably. ${ }^{74}$ Likewise, according such high priority to deficit reduction through social spending cuts has profoundly unequal effects across Canada's social spectrum, and in particular threatens to exacerbate class and gender inequalities in ways discussed in greater detail below.

References to the universal taxpayer are often accompanied by statements to the effect that this taxpayer is fatigued and that there is no further room for tax increases of any kind. The undesirability of raising taxes is often asserted not as a political preference of certain groups but as harmful or counterproductive for the economy as a whole. The Canadian Tax Foundation, for example, in a prebudget submission to an Ontario legislative committee, took a strong stand against any provincial tax increases. ${ }^{75}$ Many of the Foundation's arguments were based on its view that there is growing political resistance to higher taxes, and, consequently, a risk of incurring the "wrath of the average taxpayer," or of attracting "concerted opposition" to any new tax measure. However, economic and statistical measures were also invoked to suggest that the country is at or near its "maximum tax burden."

Though we are warned that determining the maximum tax burden is "not an exact science," the submission makes a strong implicit claim to scientificity through its ample use of quantitative indicators. It is noted, for example, that since 1980 the overall tax burden had risen about seven per cent relative to gross domestic product (GDP), and that Canadian personal income taxes sat at 14.5 per cent of GDP in 1992, compared to only 10.1 per cent in the United States. Though corporate income taxes, by contrast, were "well below" the level in other industrialized countries, no increase was advised here because of the "full mobility of capital" under free trade, and because multinational corporations can avoid taxes by shifting accounting profits to lower tax jurisdictions. The presentation of this analysis as neutral and objective truth is strengthened by the Foundation's description of itself as "an independent research organization" with expertise in fiscal policy, that "does not engage in lobbying or policy advocacy."

The statistical data presented by the Tax Foundation is presumably accurate, but again, selected bits of data cannot alone resolve what are essentially political questions about the proper level and distribution of the tax burden. Quite to the contrary, I would argue that empirical information was used here in a manner that tends to hinder rather than enhance democratic conversation about these critical value choices. Framing the argument in the

74. Lacey, supra note 51 at 553-54.

75. Canadian Tax Foundation, Submission to the Ontario Select Committee on Finance and Economic Affairs (7 February 1995). 
language of technical expertise deflects criticism of the document's own normative standpoint. A brief deconstructive effort will show that the Foundation's submission generates more questions than answers.

Taken in the abstract, a history of recent growth in the overall level of taxation casts doubt on the merits of further tax increases. When this fact is restored to its political context, however, its significance may be greatly altered. In particular, we need information about the distribution of the tax burden, and whether the wealthier sectors of society have shared equitably in recent tax increases. It should be noted that the tax lawyers and accountants who comprise the bulk of the Foundation's membership act mostly on behalf of large corporate clients rather than the "average taxpayer" invoked in the document. ${ }^{76}$ As well, the appropriateness of overall tax levels cannot be assessed without some background vision of the proper role of the state in society. It may well be that Canadians have settled on a different political vision of the state than Americans and that our current tax levels are quite modest in relation to the level of public services enjoyed by citizens. Likewise, the Foundation's assertion that governments have little power to control the tax or investment behavior of corporations is not value-neutral but suggests a particular (and currently popular) neoliberal vision of how the state should constitute itself. It also glosses over the important fact that tax rates are only one determinant of business location, along with many other factors such as access to raw materials, skilled labour, markets, and a smoothly functioning public infrastructure to facilitate industrial transportation, communication, etc.

It is perhaps tempting to discount some of the foregoing examples of deficit discourse on the basis that they were produced by advocacy groups of one kind or another, working quite consciously to further the agenda of a particular government or interest group. It is significant, however, that they do not present themselves in this way, or admit to having any normative viewpoint about public finance. Rather, they purport to offer objective information. My point is that these types of texts have significantly influenced public thinking about deficits, in part because of their image of expert neutrality. In any event, similar features can be observed in the most rigorously academic treatments of the deficit issue. A good example can be found in the debate within economics literature over the direction of causality between government spending and revenue collection.

76. For an analysis of the Canadian Tax Foundation's connections to corporate interests and its role in opposing progressive tax reforms in the 1960s and 1970s, see MacDonald, Taxing Comprehensive Income, supra note 47. 


\section{Overspending versus Undertaxing}

The causality debate starts from the premise that there is wide consensus on the need to reduce public debt and the size of government, and inquires into the most efficient means of achieving these goals. To this end, economists have sought to determine whether state spending causes higher taxation or whether the converse is true. This, in turn, generates conclusions about whether deficits are predominantly caused by overspending or by inadequate taxation. While this seems a rather tautological sort of debate, emphasizing one or the other of these causal factors can lead to radically different policy prescriptions. Whereas "supporters of higher taxes say that new revenues will balance the federal budget," 77 others insist on expenditure cuts because "increasing taxes will simply lead to more government spending." 78

Canadian economists Ahiakpor and Amirkhalkhali have usefully set out the competing arguments about the principal source of deficits. ${ }^{79}$ The "excessive spending" hypothesis, as they describe it, "emphasizes the ease with which spending programs can be extended, primarily to suit the interests of politicians," and that levels of taxation represent a "mandate" from the community about acceptable levels of spending. ${ }^{80}$ According to this view, deficits are caused by politicians' failure to respect the limits of this tax mandate. Moreover, increasing tax revenues is believed simply to lead to greater program spending by governments. The only effective way to reduce deficits, by this logic, is to make expenditure cuts. The "inadequate taxation" theory, on the other hand, presupposes that "a government is established to fulfill the vision or mandate of society," and that it is this social mandate that drives government spending and the decision to raise revenues. By this analysis, governments should accede to society's demands for more costly programs by raising sufficient tax revenues to pay for them. ${ }^{81}$

Ahiakpor and Amirkhalkhali go on to interpret historical data on Canadian government revenues and expenditures. ${ }^{82}$ They find qualified support for the "excessive spending" thesis, and conclude that "to attack the problem of persistent deficits, Canada ... should focus more on spending cuts or fiscal

77. W. Anderson, M. S. Wallace \& J. T. Warner, "Government Spending and Taxation: What Causes What?" (1985/86) 52 Southern Economic Journal 630 at 631.

78. Ibid.

79. J. C. W. Ahiakpor \& S. Amirkhalkhali, "On the Difficulty of Eliminating Deficits with Higher Taxes: Some Canadian Evidence" (1989) 56 Southern Economic Joumal 24.

80. Ibid. at $25-26$.

81. Ibid.

82. Ibid at 27-30. 
restraint rather than on finding ways of raising additional revenue from taxes." 83 What is most interesting about this article, for the purposes of my analysis, is the authors' attempt to find scientific answers to the highly political questions they raise. Much like the less academic texts discussed earlier, they suggest that the question of which hypothesis better describes the cause of deficits is an "empirical" one. ${ }^{84}$ What this tends to suppress is that both hypotheses necessarily are informed by normative values about how Canadian society should be ordered. Whereas the "excessive spending" theory constructs civil society as an aggregate of individuals determined above all to cede only limited amounts of wealth to the state, "inadequate taxation" constructs society much more as a collective with interests and goals beyond private wealth accumulation.

While empirical data may illuminate some of the implications of pursuing different political visions, it cannot by itself resolve the normative question as to what constitutes a good society. The problem, again, is that technical discourses often present their ideological predilections as neutral expertise. Indeed, according to Gonick, "[a]mong social scientists, economists are the most insistent about the value-free nature of their inquiry." 85

In the article by Ahiakpor and Amirkhalkhali, the political dimension of the preference for expenditure controls is obscured by constructing the tax mandate as something set by society as a whole, which is then disregarded by selfinterested politicians. Much like the "Economic Growth and Debt Quiz" and the Canadian Tax Foundation submission, this tends to elide inequalities among taxpayers, and the role that governments have in redistributing income and wealth from one group of citizens to another through progressive taxation and social spending. Elsewhere in the article, however, the authors exhibit a clear preference for less redistribution. Before embarking on their empirical analysis they state:

[T] here are strong a priori arguments on the side of the excessive government spending hypothesis. They include the fact that many of those who call for increased government spending on their behalf, particularly "welfare programs," pay little in taxes because they earn the least (or no) income, and are also taxed at the lowest rates. Such requests, therefore, do not necessarily represent a willingness by most income earners to cede a greater portion of their income to government ... 86

What is stated here as obvious, presumptive fact is based on highly questionable assumptions and stereotypes. Just like the quiz discussed earlier, this passage

83. Ibid. at 31 .

84. Ibid. at 26.

85. Gonick, supra note 71 at 19.

86. Ahiakpor \& Amirkhalkhali, supra note 79 at 26, 27. 
associates deficits with welfare or social spending, without regard to the evidence that such expenditures have declined over the last two decades and have contributed relatively little to the accumulation of debt. ${ }^{87}$ The amount of deficit spending that has benefited middle-class and wealthier Canadians is not explored, nor is the interest such groups have in preserving public health care, subsidized post-secondary education, or corporate tax expenditures. Lower income people are constructed as non-taxpayers or minimal taxpayers, whose views therefore must not be representative of the true tax mandate set by mainstream society. This assumes a far more progressive tax and transfer system than Canada actually has. It overlooks the fact that even those with low incomes pay substantial taxes, especially through commodity and other flat taxes that are not geared to income. ${ }^{88}$ And it ignores the further downward redistribution of the tax burden which took place in the 1980s, with the introduction of the Goods and Services Tax and the flattening of the marginal rate structure in the $I T A{ }^{89} \mathrm{It}$ seems likely that these authors' strong a priori views helped shape their selection and interpretation of the empirical data.

Indeed, differences in political vision may help to account for the diversity of economic opinion in this area. In the American context, Anderson, Wallace and Warner concluded that federal government spending leads to higher taxes rather than the reverse. Their study, they assert, "support[s] a view of the world in which the political system somehow determines how much to spend and then looks for revenue sources to finance that level of spending ..."90 Though Anderson et al. do not state a preference for higher taxes as the best response to deficits, their sense that government is driven by a political mandate rather than a fiscal one accords well with the "inadequate taxation" thesis rejected by Ahiakpor and Amirkhalkhali, and its different assumptions about what motivates citizens and governments.

In this section and the previous one, I have focused on interrogating the truth claims asserted by dominant discourses on the deficit, and how their emphasis on rational expertise closes down political debate. I have also argued that ideologically specific norms and values are introduced into these technical discourses through the selection of relevant data, appropriate comparators, and $a$ priori assumptions. In the next section, I extend this analysis to the metaphors of deficit talk.

87. See supra note 69.

88. See Low Income Tax Relief Working Group Report (Ontario Fair Tax Commission, December 1992).

89. Brooks, supra note 7.

90. Anderson, Wallace \& Warner, supra note 77 at 630 . For a view that lies somewhere in between, see R. Ram, "Additional Evidence on Causality between Government Revenue and Government Expenditure" (1987/88) 54 Southern Economic Journal 763. See also J. Cullis \& P. Jones, Public Finance and Public Choice (London: McGraw-Hill International, 1992) at 376-93. 


\section{The Metaphorical Deficit}

The many vivid metaphors that are used to talk about public deficits provide a further set of clues about the submerged normative content of the discourse. In particular, the sense of crisis that pervades much of the literature is often cultivated metaphorically. We hear of the "debt tinderbox," the "crushing debt," and the "voracious compound interest treadmill." 91 We are told that our "massive addiction"92 to borrowing has led to a "corrosive growth"93 of debt, placing us on a "collision course"94 with our "darkening economic vistas." $95 \mathrm{We}$ suffer from the "crippling"96 effects of "The Plague of the Black Debt," 97 and are admonished to "rein in," "reel in" and "lance the debt boil." 98 What is more, Finance Minister Martin informs us that "temporary fiscal remission" is not enough, and the country must pursue "full fiscal health." 99

The presence of metaphors should not necessarily be taken as a sign of weak reasoning, nor as a mere matter of ornamentation. Rather, as Donald McCloskey has argued in the context of economics, sound analysis requires the careful use of metaphors and storytelling, as much as it requires logic and fact. ${ }^{100}$ This is part of the process whereby normative ideals and bodily experiences are integrated into empirical thought. McCloskey also defends social scientists' use of rhetoric: "An economist or a historian cannot avoid writing rhetorically since any argument has a rhetoric, a style of argument, taking 'argument' to mean 'any designs on the reader'." 101 The real problem, in his view, is the reluctance of economists to acknowledge the normative aspect of their analyses, and to reflect critically upon the aptness of their metaphors and stories to describe and prescribe things about human society. ${ }^{102}$

91. J. S. McCallum, "Debt Policy and Debt History" (1994) 15:5 Policy Options 37.

92. Bank of Novia Scotia chief economist Warren Jestin, quoted in The Financial Post (3 June 1994) 1.

93. "Martin Takes Aim at $\$ 600$-Billion" The [Toronto] Globe and Mail (16 September 1994) A20.

94. "60 Minutes" (13 May 1994).

95. D. Frum, "In the Hole" Saturday Night (February 1995) 42.

96. Financial Post (16 September 1991) 1.

97. J. D. Davidson, The Plague of the Black Debt: How To Survive the Coming Depression (Baltimore: Strategic Investment, 1994).

98. "A Well-Crafted Package Can Do More than Lance the Debt Boil" (excerpt from C. D. Howe Institute) The [Toronto] Globe and Mail (12 October 1994) Al.

99. Budget Speech (Ottawa: Department of Finance, Canada, 1995) at 6.

100. D. McCloskey, If You're So Smart: The Narrative of Economic Expertise (Chicago: University of Chicago Press, 1990) at c. 1. See also Postman, supra note 26 at c. 9.

101. McCloskey, ibid. at 56.

102. Ibid. at c. 4 . 
The frequent use of cataclysmic metaphors to tell the story of the deficit betrays the presence of a strong argumentative agenda in the dominant discourse. As I suggested earlier, these devices help to garner support for an urgent pace of deficit reduction. Similarly, feminist theorists have shown how metaphors can introduce particular images of, and ideas about, women into scientific knowledge and practice. ${ }^{103}$ In this regard, it is interesting to note how often the deficit is metaphorically constructed as a natural or bodily force out of control that must be mastered by human will and knowledge. There is a connection here to the Cartesian anxiety described by Bordo with its emphasis on masculine control of the natural universe through the rigours of scientific rationality. ${ }^{104}$ The historical association of women with nature, the body, and the irrational aspects of human existence may be one reason why feminist arguments about alternative approaches to fiscal policy often face an uphill battle. Marjorie Cohen has noted a tendency to discount the views of women's organizations on broad issues of economic policy: "[when] we began to talk about economic issues like the budget, trade policy, privatization, deregulation, and the general structure of the Canadian economy, we were going too far. These were not women's issues: women were not 'experts' and therefore our criticism had little credibility." 105 In another's words, the expectation is that "[w]omen do the research on gender; men do the research on the economy."106 This exclusion of feminist analyses from economic policy making is problematic in light of the profoundly gendered impact of fiscal restraint.

103. See, for example, E. Martin, The Woman in the Body: A Cultural Analysis of Reproduction (Boston: Beacon Press, 1987); "Language and Science: Genetics, Embryology, and the Discourse of Gene Action" in E. Fox Keller, ed., Refiguring Life: Metaphors of Twentieth-Century Biology (New York: Columbia University Press, 1995).

104. Bordo, supra note 22. Lacey, supra note 51 at 553, also notes the masculine overtones of metaphors surrounding the efficient, managerialist state, especially the emphasis on better "performance" by government agencies

105. M. Cohen, "The Canadian Women's Movement and its Efforts to Influence the Canadian Economy" in C. Backhouse \& D. Flaherty, eds., Challenging Times: The Women's Movement in Canada and the United States (Montreal: McGill-Queen's University Press, 1992) 215 at 218-19, quoted in Brodie, supra note 65 at 47.

106. M. MacDonald, "Restructuring in the Fishing Industry in Atlantic Canada" in I. Bakker, ed., The Strategic Silence: Gender and Economic Policy (London: Zed Books in association with North-South Institute, 1994) 91 at 100. 


\section{The Gendered Impact of Fiscal Austerity}

Earlier in this part, I made reference to the disproportionate impact of reduced social spending on low income people. ${ }^{107}$ Materials filed in the Masse case ${ }^{108}$ the constitutional challenge to the reduction of welfare rates in Ontario-detail the physical, psychological and social harms inflicted when people lose access to adequate food, shelter, heating, and other basic requirements of subsistence. The case also highlights the intricate ways that low-income status interacts with other forms of social disadvantage, showing how welfare cuts impose specific kinds of costs on poor women and their children, and on low-income people with disabilities. For individual applicants, the reductions meant a loss of autonomy and control over matters as fundamental as the custody of children, the decision to remain separated from an abusive husband, and whether to place a disabled child in institutionalized care. ${ }^{109}$ At a more general level, because women are overrepresented among the poor, they are more likely to require social assistance and other social services, and to suffer from their removal.

Martha Jackman has pointed out that the abolition of the Canada Assistance Plan as of 1 April 1996 has particularly negative implications for women. ${ }^{110}$ Not only will total federal funding for provincial social programming decline substantially, but most of the national standards governing provincial welfare plans will be removed, including the right to assistance based on need, whatever the reason for the need, and the requirement that provinces take into account the basic requirements of living in setting welfare rates. Nor can women be assured that provincial governments will continue to allocate funds for previous shared-cost programs such as civil legal aid, sexual assault counselling, and subsidized child care, or for transition houses. 111

In addition to the fact that women disproportionately must rely on social services, many women are employed by government agencies and will lose their jobs as the civil service is reduced. The cuts also impact on women in their domestic roles, often meaning that "social services are shifted from the paid work of women in the public sector to the unpaid labour of women in the domestic sphere." 112 Reductions in the availability of public child care, health care, education spending and welfare incomes resuits in a privatization of more caring work within families, most often to be absorbed by women. At the same time, these changes heighten the barriers to women's equal participation in the paid labour force. The decreasing commitment of state resources to programs

107. See supra note 70 and accompanying text.

108. Ibid.

109. Factum of the Applicants, paras. 65-109.

110. M. Jackman, "Women and the Canada Health and Social Transfer: Ensuring Gender Equality in Federal Welfare Reform" (1996) 8 C.J.W.L. 372.

111. Ibid. at 10 .

112. Brodie, supra note 65 at $19-20$. 
like pay equity and affirmative action exacerbate this effect. ${ }^{113}$ Expenditure restraint must be seen as one aspect of a larger renegotiation of the relationship among families, the state, and the market, which is in turn dependent upon particular unequal gender relations.

Clearly, then, there is a pressing need for feminists and others interested in greater social equality to address fiscal policy issues, and to contend with the technical discourses that pervade this area. In the final part of the paper, I examine how the power of technical language manifested itself in the Symes and Thibaudeau cases, two recent feminist challenges to the income tax system. I argue these decisions hold a number of lessons about the potential of technical discourses both to advance and to hinder feminist legal and political arguments in the fiscal sphere.

\section{Feminist Challenges to Fiscal Discourse}

The question raised in this part is how feminists can best engage with technical discourses in the effort to obtain reforms to the tax system and the larger fiscal order. At one level, this is simply a new version of an old problem for feminists: the need to expose the contingent nature of seemingly objective and universal concepts, rules, and social arrangements. The tax system poses a distinct challenge, however, because of the extraordinary degree to which it is dominated by expert knowledge. As discussed in Part I, tax law's association with other technical discourses, such as economics and accounting, strengthens its claim to scientificity. This inhibits critical conversation about tax laws by those defined as non-experts (including, sometimes, judges), and tends to delegitimize overtly value-based critiques of taxation.

The centrality of experiential knowledge to much feminist theorizing makes it appear less objective than the kinds of abstract quantitative reasoning traditionally employed within discourses like accounting and economics. Additionally, feminist challenges to the tax system often have to do with the treatment of women's caregiving work, with all its bodily, emotive, and expressive associations. ${ }^{114}$ Because it is constructed as the epitomy of rational,

113. For an overview of the gendered implications of economic restructuring policies, see I. Bakker, "Engendering Macro-Economic Policy Reform in the Era of Global Restructuring and Adjustment" in I. Bakker, ed., supra note 106, 1; M. Griffin Cohen, "The Implications of Economic Restructuring for Women: The Canadian Situation", ibid. 103.

114. The Women and Taxation Working Group, supra note 12, executive summary at I, made this point as follows: "[W]omen's primary responsibility for the young, the sick and the frail elderly is a critical factor in contributing to women's inequality and in determining the impact of the tax system on women as compared to men. As 
economic legislation, tax law seems particularly resistant to any form of challenge which appears to be perspectival or personal. I do not suggest this is the only factor working against feminist challenges to fiscal policy. Rather, as I stated at the outset, technical discourses complement other layers of politics.

The judicial treatment of feminist arguments in the Symes and Thibaudeau cases helps to illustrate these difficulties. These cases also raise some hard questions about when and how fiscal feminists draw upon technical discourses to advance their own arguments. While these discursive strategies have some liberatory potential, there are also risks associated with "putting the new wine of critical ... theory into the old bottles of patriarchal linguistic categories." 115 A brief summary of the cases is in order.

Beth Symes, a partner in a law firm, argued that the cost of hiring a nanny to care for her young daughters should be fully deductible as a business expense, either on a proper interpretation of the ITA, or pursuant to the equality rights provision in s.15 of the Charter of Rights and Freedoms. The core of her argument was that Revenue Canada's construction of child care expenses as personal rather than business-related is gender-biased; it reflects a world view in which women and their domestic activities are seen as private and separate from the public sphere of commerce, and in effect perpetuates women's exclusion from the business world. At trial, Cullen J. agreed with Symes, holding the nanny's salary to be fully deductible. ${ }^{116} \mathrm{His}$ decision was reversed by the Federal Court of Appeal. ${ }^{117}$ The Supreme Court of Canada dismissed Symes' appeal, holding that Revenue Canada's denial of the deduction was justified under the terms of the statute, and that there was no violation of Symes' sex equality rights. ${ }^{118}$ The majority was comprised of the seven men on the Court-the two women dissented.

Shortly after the Supreme Court's decision in Symes, the Federal Court of Appeal ruled in favour of another woman, Suzanne Thibaudeau, who challenged the taxation of her child-support payments. The Court accepted Thibaudeau's argument that the ITA discriminated against her as a separated custodial parent by requiring her to include child support in income while allowing a deduction to her former husband. ${ }^{119}$ Writing for the majority, Hugessen J.A. held that the inclusion requirement discriminated on the basis of family status, which he identified as a ground analagous to those enumerated in s.15 of the Charter.

a result ... the working group focused on the interaction of the tax system with this unpaid work."

115. Curry Jansen, supra note 48 at 198.

116. Symes v. The Queen (1989), 89 D.T.C. 5244 (F.C.T.D.).

117. Queen v. Symes (1991) 91 D.T.C. 5397 (F.C.A.).

118. Symes, supra note 3.

119. (1994) 114 D.L.R. (4th) 261. The so-called deduction/inclusion system is set out in s. 56(1)(b) and s. 60(b) of the ITA. The federal government announced the proposed repeal of these provisions as of 1 May 1997 in its 1996 budget. 
Hugessen J.A. rejected the intervenor's argument that the provisions discriminated on the basis of sex, however, despite the fact that virtually all persons paying tax on child support are women, and despite broad evidence of women's post-divorce poverty relative to men. ${ }^{120}$

The government appealed the Thibaudeau case to the Supreme Court of Canada and won. ${ }^{121}$ As in Symes, the majority rejected the equality challenge, holding that the impugned provisions imposed no burden on Thibaudeau. Two factors were central to this decision. First, the majority chose to focus on the aggregate impact of the inclusion/deduction system on the (ex-) couple, reasoning that the tax system actually confers a benefit by allowing the parents to split their incomes and reduce the net tax burden on their combined incomes. In response to the argument that in practice the custodial family often derives no benefit from this tax subsidy and is sometimes prejudiced by the inclusion requirement, the majority turned to the family law system. Any such inequality between the ex-spouses is caused not by the tax system, they said, but by the failure of family law processes to ensure an adequate level of support. Once again, the Court split along gender lines. The two women Justices, McLachlin and L'Heureux-Dubé JJ., would have struck down the inclusion requirement on the view that it discriminates against the custodial parent.

These two Supreme Court decisions have attracted a number of academic commentaries. ${ }^{122}$ My purpose here is to make a few points about the role of technical discourses in these cases and the way such discourses both advanced and thwarted feminist arguments. In both cases, statistical and social science evidence was introduced to advance arguments for a feminist, or at least a more gender-neutral tax law. In Symes, the taxpayer brought in a feminist sociologist to testify to the increasing role of women in the paid labour market, and the barriers posed to women due to their primary caregiving responsibilities. In Thibaudeau, the parties and intervenors submitted studies on the financial

120. In a highly problematic passage of his judgment, ibid. at 27I, Hugessen J.A. concluded that the different treatment of payers and recipients of child maintenance is not linked to sex because some men, though relatively small in number, are also subject to the inclusion requirement. The fact that women make up $98 \%$ of this group was not, in his view, sufficient by itself to establish an adverse effect on women as a class. For a detailed analysis of the judgment see Philipps \& Young, supra note 15.

121. Thibaudeau, supra note 4.

122. See, for example, Macklin, supra note 15; L. Philipps, "Thibaudeau v. Canada: Tax Law: Equality Rights" (1995) 4 Can. Bar Rev. 668; Philipps \& Young, supra note 15; C. Young, "Child Care and the Charter: Privileging the Privileged" (1994) 2 Review of Constitutional Studies 20; E. Zweibel, "Thibaudeau v. R.: Constitutional Challenge to the Taxation of Child Support Payments" (1994) 4 N.J.C.L. 305. 
impact of the taxation of child support on men and women across income brackets.

These strategies are attractive because they can confer additional authority on feminist arguments. They may allow us to capitalize on the positive, democratic potential of scientific and technical knowledge, that is, its appeal to a rational order superior to entrenched traditions or prejudices. An example of this type of discursive strategy is evident in the history of litigation over sexual orientation discrimination in Canada. Didi Herman has remarked upon the judicial tendency to rely on sociological evidence to support innovative and progressive interpretations of the law and to reject earlier interpretations as the product of uninformed biases. ${ }^{123}$ Indeed, I myself have enlisted statistics, social science writings and other technical materials in this paper, in my effort to challenge prevailing views on budget deficits. It is also true that the choice of discursive strategy in any context is constrained in part by the existing framework of debate. In many cases, feminists have little choice but to respond to the technical arguments held up to justify the status quo. However, it is important to recognize the potential pitfalls in trying to beat tax law at its own technical game, and the subtle ways in which technical discourses may undermine feminist politics even as they advance the immediate interests of particular women.

First, we must be conscious that feminist social science or other expertise is not entering a vacuum when it is presented in tax cases. Besides having to contend with the political predispositions of individual judges, it is up against other technical knowledge systems like economics and traditional tax policy analysis. The gendered assumptions of these other discourses have already been deeply internalized within the jurisprudence and provisions of tax law. As Herman writes in the context of equality litigation by lesbians and gay men:

[W]hat judges "know" about homosexuality is less a consequence of "expert" courtroom interventions, and more the result of the sexual politics they bring to the decision-making process-a politics informed by their social location and experience, as well as any or all of several other sources, including religion, psychiatry, biology, feminism, and sociology. ${ }^{124}$

An example of the influence of extra-legal knowledge can be seen in the Thibaudeau case, in the majority's reliance upon a traditional economic concept of the family unit. Mainstream economic theory has tended to reduce heterosexual family groupings to their male breadwinners, presuming that an increase in men's welfare benefits all members of the household. Even in more reflective theories which recognize that families are comprised of individuals,

123. D. Herman, Rights of Passage: Struggles for Lesbian and Gay Legal Equality (Toronto: University of Toronto Press, 1994) at c. 7.

124. Ibid. at 140 . 
men are generally assumed to pool their incomes with women and children, who are assumed to be earning less market income. ${ }^{125}$

As many critical scholars have exposed, this image of the heteropatriarchal family is founded on assumptions which may be accurate for some but which grossly distort the experience of many. The assumption of a male breadwinner, for example, does not reflect the realities of many working-class women and women of color, whose waged work has been critical to the survival of their families. ${ }^{126}$ Further, in families where men are the primary earners, economic theory exaggerates the degree to which intra-family relations are characterized by altruism and equal sharing. Indeed, central to the feminist arguments in Thibaudeau was the reality of economic inequality within heterosexual marriages - the fact that women frequently do not benefit equally from market incomes received by men, and that men do not necessarily share their incomes willingly, especially following separation.

Despite the evidence offered to them, the majority judges in Thibaudeau were unable or unwilling to see any problem with treating the heterosexual family as a unified economic entity. They concluded the deduction/inclusion system is not burdensome for women, and in fact generally confers a benefit, because it allows for co-operative income splitting which increases the resources available to support the children. In their words:

[W]e are ... dealing with two provisions geared to operate at the level of the couple. They are designed to minimize the tax consequences of support payments, thereby promoting the best interests of the children by ensuring that more money is available to provide for their care. If anything, the legislation in question confers a benefit on the post-divorce "family unit." It is clear that the divorced parents still function as a unit when it comes to providing financial and emotional support to their children ... 27

Likewise, Gonthier J. reasoned that the provision of a deduction to the ex husband "results in relief for the couple and a greater ability to pay and hence an incentive to pay." 128 The statistical and social science evidence, cited abundantly by the two women Justices in dissent, indicated that in almost 30 per cent of cases there is no potential for income splitting at all, because the woman is earning as much or more income than her former husband, and consequently is

125. See M. Cohen, "The Problem of Studying Economic Man" in A. Miles \& G. Finn, eds., Feminism in Canada: From Pressure to Politics (Montreal: Black Rose, 1982); see especially J. A. Nelson, Feminism, Objectivity \& Economics (London: Routledge, 1996) at c. 5 ("Towards a Feminist Theory of the Family").

126. See, for example, S. A. M. Gavigan, "Paradise Lost, Paradox Revisited: The Implications of Familial Ideology for Feminist, Lesbian and Gay Engagement to Law" (1993) 31 Osgoode Hall L.J. 589.

127. Thibaudeau, supra note 4 at 702 , per Iacobucci and Cory JJ.

128. Ibid. at 698 . 
not in a lower tax bracket. They also cited evidence that family courts often have not adequately accounted for the tax implications of support, and noted that, in any event, the great bulk of support arrangements are negotiated in private, without court supervision, and often without lawyers or tax advice. In addition, the clear evidence that women's standard of living declines relative to men's following divorce suggests that the sense of sharing and mutual obligation assumed by the majority is not a reality for many people.

Perhaps most striking is that the majority did not discuss the social science evidence submitted by the taxpayer or the intervenors, even to indicate why they rejected it. This ability to silently disqualify feminist expertise is a particular concern given that judges are often asked to choose between two or more expert opinions, potentially advantaging whatever appears on a superficial level to be the best science. It seems likely that courts will very often find studies which proceed from dominant assumptions to be more objective and authoritative. Moreover, corporate and state interests have far greater resources than women's groups or anti-poverty organizations to produce technically sophisticatedlooking research. There is likely to be a hierarchy of technical discourses, in other words, in which expert evidence perceived as feminist will often be seen as less objective.

Perhaps the best evidence of technical knowledge exercising power in Thibaudeau, however, is the special deference accorded to tax law and traditional tax policy concepts by the majority. While being careful to state that tax legislation is not exempt from Charter review, they emphasized the importance of not interfering unduly with the government's fiscal priorities. Gonthier J. argued most strongly for this deferential approach, pointing to the ITA's "special nature," ${ }^{129}$ and admonishing the taxpayer as follows:

[O]ne should not confuse the concept of fiscal equity, which is concerned with the best distribution of the tax burden in light of the need for revenue, the taxpayers' ability to pay and the economic and social policies of the government, with the concept of the right to equality, which ... means that a member of a group shall not be disadvantaged on account of an irrelevant personal characteristic shared by that group. ${ }^{130}$

Gonthier J.'s comments are a more developed version of what Létourneau J.A. said in his dissent in the Federal Court of Appeal: "The Income Tax Act is essentially economic legislation, which may even be described as amoral."'131

These statements appeal to the notion that tax law has its own internal logic and imperatives that operate beyond the reach of politics. Fiscal policy is constructed as something governed by a higher authority of objectively

129. Ibid. at 675 .

130. Ibid. at 676.

131. Supra note 119 at 289. 
determined criteria which even the Court is less than fully qualified to review. Reframing the issue as one of fiscal equity removes it neatly from the sphere of equality discourse into the expert language of tax policy. Gonthier J.'s distinction is nonsensical, of course, because notions of fiscal equity rely on precisely the same ideologically charged standards and beliefs as equality rights doctrine. Indeed, the political contingency of tax interpretation is demonstrated by the majority's invocation of the so-called post-divorce family unit in Thibaudeau, as discussed above. Again, however, arguments that are perceived as feminist or otherwise politicized may be effectively disqualified when tax law is constructed as a specialized body of knowledge.

One response to these difficulties is simply to accept them. Feminists must always contend with more powerful, masculinist discourses in the courts, in academe, in the popular media and in policy making processes. If greater use of empirical data and expert languages can narrow the odds against us by creating a more authoritative feminist discourse, some would argue this is enough. It is significant, for instance, that both Symes and Thibaudeau managed to convince one court on the way up, as well as both women judges on the Supreme Court of Canada, in the process generating a body of dissenting jurisprudence that may show the way forward in future cases. And the political controversy and lobbying activities generated by Thibaudeau's case undoubtedly were a major influence in the government's decision to propose the repeal of the inclusion/deduction rules in its 1996 budget. It is entirely possible that the marshalling of technical discourses in support of Thibaudeau's position played some role in bringing about progressive change. Even if this is so, however, a couple of potential problems remain.

There is a risk that addressing problems of sexism and other social biases with scientific research may encourage the same kind of depoliticization that occurs when such research is used to support dominant ideological positions. The basic political and moral questions being raised by feminists may be translated into technical matters for specialists to debate. A different but related problem is that the subtle normative thrust of expert discourses may operate at cross-purposes with the feminist political aims they were invoked to serve. The Symes case provides an example.

In the successful litigation at the trial level, Cullen J. picked up on the evidence given by the feminist sociologist, making it a central part of his reasons. It is worth quoting him at some length:

[T]he plaintiff exercised good business and commercial judgment in deciding to dedicate part of her resources from the law practice to the provision of child care. This decision was acceptable according to business principles which include the development of intellectual capital, the improvement of productivity, the provision of services to clients and making available the resource which she sells, namely her time ... Further, [the expert] evidence supports the notion that the availability of child care increases productivity by 
enhancing the peace of mind of employees. Enhancing productivity is ... totally in keeping with well established business practices. Moreover, [the expert] evidence indicates that the absence of child care is a barrier to women's participation in the economy ... and therefore lowering the barrier by arriving at a satisfactory means of dealing with the costs of child care would make good business sense. ${ }^{132}$

While this line of reasoning helped support a decision in favour of Symes, it is important to reflect on the larger implications of framing the issue of child care in these terms. For most of the above passage, Cullen J. distances himself from the feminist political arguments in favour of state-subsidized child care. $\mathrm{He}$ does refer to the barriers to women's participation in paid labour, but quickly translates this back into a question of "good business sense," rather than sexual equality. Moreover, the passage is far removed from any sense that child care work is itself a socially and economically valuable activity, or that it would be a good idea to distribute that work more equally between men and women. Framing the issue in these narrow economistic terms also leaves the class and racial politics of the private model of child care services completely unproblematized. Audrey Macklin has detailed the vulnerability of immigrant women, particularly women of colour, to economic, physical and sexual exploitation as domestic workers. ${ }^{133}$ Nor does the decision address in any way the situation of the vast majority of women who do not earn business income, and their lack of access to affordable child care. Does this judgment introduce a feminist discourse into the field, or does it translate the feminist political challenge into a technical question that fundamentally endorses existing economic relations and their attendant inequalities?

One may argue that these problems simply reflect the limits of equality rights litigation, with its inevitable focus on a narrow legal issue. It is notable, however, that the economic discourse used by Cullen J. is so well suited to the task of placing the larger political issues aside. One may also argue that the business woman and the domestic worker have a common political interest in any change that attaches greater economic importance to women's work. However, the language of the Tax Court decision by no means encourages this connection, with its tight focus on the efficient generation of profit in the paid economy.

I do not wish to suggest that feminists should reject science out of hand as a way of knowing and changing the world. A technical rendering of the child care issue in terms of human capital and productivity does after all capture some part of some women's experience. ${ }^{134}$ What is needed, however, is to revise the

132. Supra note 116 at 5249 .

133. A. Macklin, "Foreign Domestic Worker: Surrogate Housewife or Mail Order Servant?" (1992) 37 McGill L.J. 681. See also Macklin, supra note 15.

134. I thank Nancy Staudt for helping me clarify this point. 
concept of science and objectivity to recognize the locatedness and partiality of all knowledge. Chris Weedon's admonition is useful here:

[W] hile we need to develop ...a concept of feminist rationality, which is different from the rationality of patriarchy, and which no longer dismisses feminine qualities as they are currently defined as irrelevant and inferior, we cannot afford to abandon reason entirely to the interests of patriarchy. Reason, like experience, requires both deconstruction and reconstruction in the interests of feminis[m]. ${ }^{135}$

I have several suggestions as to how this challenge might be taken up in the fiscal policy field. First, those working for change need to be alert to the contradictions of technical discourse and the ways it may undermine political struggles around deficits and taxation even while supporting immediate law reform struggles. Second, it would be useful, I think, to push the technical discourses themselves in a more radical direction whenever possible. In Symes, for example, it might have been possible to draw on the work of feminist political economists to talk about the productive value of child care labour itself, and the way women's caregiving work subsidizes profitability in the public economy. This would be an alternative means of challenging the construction of women's family responsibilities as private and noneconomic, in a way that permits a more radical critique of the division of labour and its effects on different groups of women. In other words, it is worth considering how to challenge the gender, class and other biases within technical discourses, when we are deploying them to achieve progressive change in the law. Finally, it is critical in my view to resist the technocratic ideology of value-neutrality, and to keep the political and moral issues that are at stake in the foreground of any analysis. While it may be necessary and worthwhile to counter arguments justifying the current fiscal system on their own terms, it is equally important to expose the partiality and contingency of technical renderings of fiscal policy and to insist on democratic discussion of the political merits.

135. Weedon, supra note 32 at 10. 